\title{
Evaluation of the energy performance and cost-benefit of innovative technologies in butcher's shops
}

\author{
Jeroen Lippens, Saar Lokere, Wout Barbary and Hilde Breesch* \\ KU Leuven, Department of Civil Engineering, Building Physics and Sustainable Design, Ghent Technology Campus, Belgium
}

\begin{abstract}
The $\mathrm{CO}_{2}$ emissions and energy use of SMEs in the tertiary sector (e.g. small food and non-food shops, restaurants, offices, pubs, etc.) are high and there are few initiatives to reduce because this target group is difficult to reach due to small scale and diversity. The Flemish-Dutch TERTS project wants (1) to make the sector aware of the potential of and (2) to demonstrate energy transition and energy efficiency of innovative technologies. This paper is focussing on butcher's shops. A reference model is made based on data of 90 existing shops in Flanders (Belgium). The energy use of the building and systems is calculated according to DIN V 15 899. The cost-benefit of various measures is calculated and compared. Results show that the main energy consumers of a butcher shop are cooling, lighting and domestic hot water, whereas heating only has a rather small contribution. There are several cooling needs: product-cooling (in walk-in freezers, walk-in coolers and the cooling counter) and cooling of the workshop. The combination of the following measures is concluded to be the most favourable and leads to a reduction in final energy consumption of $60 \%$ : a reflective coating on the flat roof and extra roof insulation, relighting with LED, air-to-water heat pump for the generation of domestic hot water and PV panels as local energy generation.
\end{abstract}

\section{Introduction}

The $\mathrm{CO}_{2}$-emissions and energy use of SMEs in the tertiary sector (e.g. small food and non-food shops, restaurants, offices, pubs, etc.) are high. Figure 1 shows these emissions for the broader commercial and services sector for Flanders (Belgium) [1]. There are few initiatives to reduce this energy use because this target group is difficult to reach due to small scale and diversity. However, it is important to include this sector to fulfil Europe's ambition to become climate neutral in 2050. The Flemish-Dutch TERTS project [2] wants (1) to make this sector aware of the potential of and (2) to demonstrate energy transition and energy efficiency of innovative technologies. Therefore, guidelines will be defined showing interesting innovative technologies for each target group including costs and benefits.

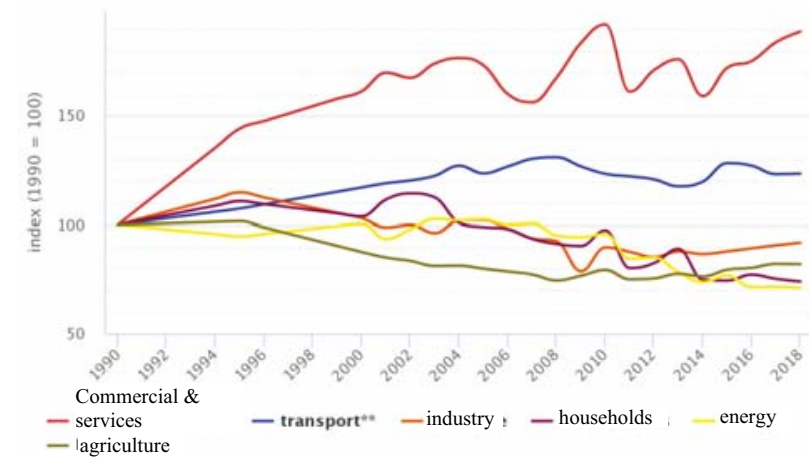

Figure 1 Relative evolution of greenhouse gas emissions per sector in Flanders since 1990 [1]
These innovative technologies include circular insulation materials (e.g. hemp), electrochromic glazing, production of renewable energy (i.e. building integrated PV, reversible heat pump, micro cogeneration), HVAC systems like cooling storage system with heat recovery, natural refrigerants and combinations with PV, lighting (e.g. controllable LED), sector specific appliances, storage (e.g. geothermal storage, fuel cell, Li-ion battery) and collective energy management systems [3].

Target groups in this study are defined as follows: hotel, restaurant, pub, butcher's shop, baker's shop, shop (food), shop (non-food), small office [4].

This paper is focussing on butcher's shops, i.e. commercial buildings with a large need of product cooling, also including fish, cheese and vegetables shops. A representative use of the electricity in butcher's shops is shown on Figure 2 [4].

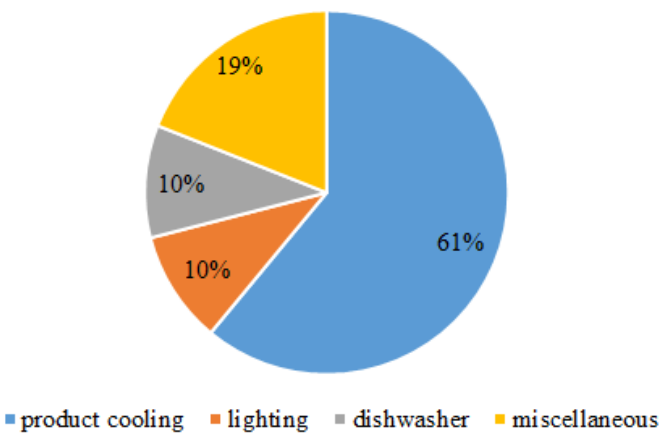

Figure 2 Electricity use in butcher's shops [4]

\footnotetext{
* Corresponding author: Hilde.Breesch@kuleuven.be
} 
The objective of this paper consists of the identification of the most cost-optimal technologies to improve energy performance of SME buildings, represented by butcher's shops. This paper is based on [5].

First, the method to determine the reference building is presented, followed by the description of the energy calculations and the cost-benefit analysis. The results section includes three parts. First, the reference building with its shape, zoning, construction type, use and systems is discussed. Second, the selection of technologies that are studied, is described. Third, the results of the cost-optimal study are presented. Finally, conclusions from this study are defined.

\section{Method}

\subsection{Reference building}

First, a reference building model of a butcher's shop is made. The geometry is based on an analysis of data of 90 existing shops in three cities in Flanders (Ghent, Brugge and Diksmuide): typology, dimensions of the façade and building, floor area and window area are determined. The zoning is defined based on plans of real butcher's shops. Building characteristics are determined via comparison of building data to the database of TABULA [6] where the construction year gives an estimation of the U-value of the building envelope. The use of store and workshop are derived from interviews with butcher's shops. Properties of domestic hot water, ventilation and heating system are based on TABULA database [6]. The cooling and lighting systems are modelled based on inspection of real butcher's shops.

\subsection{Calculation final energy use}

The energy consumption of the building and systems is calculated according to DIN V 18599 [7] using the Energieberater 18599 3D PLUS software [8]. As no temperature below $0^{\circ} \mathrm{C}$ can be simulated, the cooling energy use of the walk-in cooler and freezer are estimated using design software for coolers [9].

\subsection{Cost-benefit analysis}

The measures applied to the reference building are evaluated on the basis of net present cost (NPC) and the internal rate of return (IRR). The NPC represents the sum of the initial investment and all annual costs (i.e. energy and maintenance costs) and residual values discounted to the investment start year (year zero) based on the real market interest rate and the useful lifespan. The IRR is the weighted average annual return of the investment over the lifespan. In other words, it is the discount rate at which the NPV of the investment equals zero.
Following assumptions are made. Initial investment costs do not include VAT and are gathered through surveys with different suppliers and verified with standard prices. Two scenarios of investment costs are studied. The first scenario includes the entire investment amount, i.e. the scenario in which the system is replaced when it does not yet need to be replaced. On the contrary, the second scenario only takes into account the extra cost compared to the standard technology because this scenario assumes that the system is replaced when it needs to be replaced anyway.

Annual maintenance costs and lifespan are only included for ventilation, cooling, heating and based on EN 15459-1:2017 [10]. Annual energy costs only take into account energy for heating, cooling and ventilation and are based on energy prices for non-residential use as stated on Eurostat in 2019 [11]. Price for electricity and natural gas are assumed to be respectively $0.244 € / \mathrm{kWh}$ and $0.04 € / \mathrm{kWh}$. Increase of these energy prices is assumed according to the guidelines of the European Commission [12], i.e. $1.39 \%$ and $2.65 \%$ for electricity and gas respectively. Disposal costs are not considered in this study.

The discount rate determines the weight placed on investments in the present versus future costs and benefits. From microeconomic point of view, the discount rate has to reflect the opportunity cost of capital or the expected rate of return for the building owner. The discount rate is assumed to be $3 \%$.

\section{Results}

\subsection{Reference building}

\subsubsection{Geometry and zoning}

Boxplots are made of the width of the façade and store, the floor area, the building depth and window area. Figure 3 shows the median value of $10.5 \mathrm{~m}^{2}$ for the window area or a window-to-wall ratio of $44 \%$ and a median façade width of $8.5 \mathrm{~m}$. Median value of building and shop floor area are $162 \mathrm{~m}^{2}$ respectively $40 \mathrm{~m}^{2}$, as shown on Figure 4. In addition, $78 \%$ of the studied buildings are terraced houses.

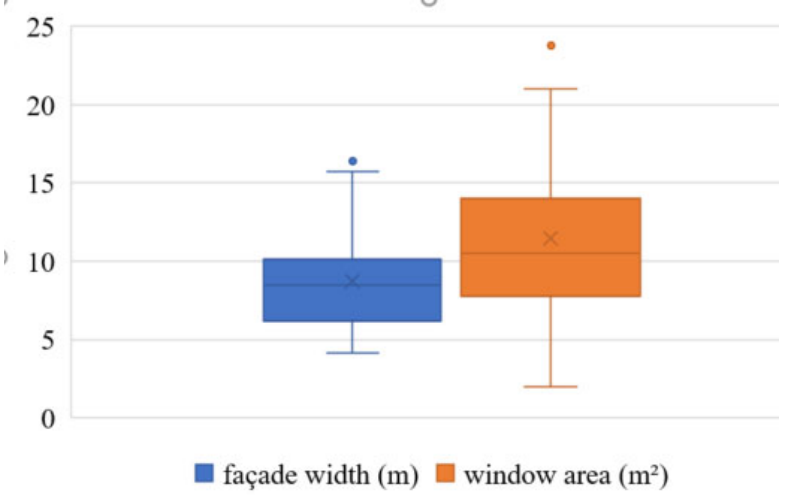

Figure 3 Boxplot of façade width $(\mathrm{m})$ and window area $\left(\mathrm{m}^{2}\right)$ of the studied buildings. 


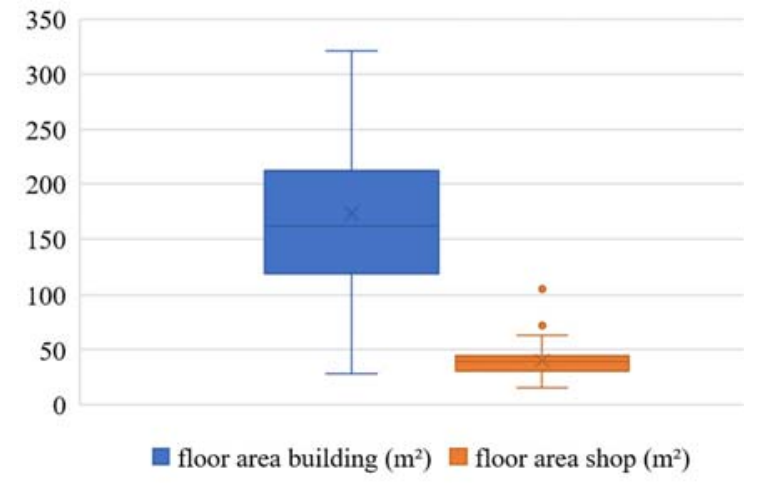

Figure 4 Boxplot of building and shop floor area $\left(\mathrm{m}^{2}\right)$ of the studied buildings.

A 3D model of the reference building is composed based on the analysis of these data. The butcher's shop includes a store, workshop, kitchen, technical room, 3 walk-in coolers and 1 walk-in freezer. Table 1 shows the properties of these zones including floor area, temperature and illuminance level. The 3D front view, section and the floor plan (including the zoning) can be found on Figure 5, 6 and 7 respectively.

Table 1 Zoning of the reference building

\begin{tabular}{|c|c|c|c|}
\hline Zone & $\begin{array}{c}\text { Floor } \\
\text { area }\left(\mathbf{m}^{\mathbf{2}}\right)\end{array}$ & $\begin{array}{c}\text { Temperature } \\
\left({ }^{\circ} \mathbf{C}\right)\end{array}$ & $\begin{array}{c}\text { Illuminance } \\
(\mathbf{L x})\end{array}$ \\
\hline Store & 40.1 & 18 & 750 \\
\hline Workshop & 64.9 & 12 & 500 \\
\hline $\begin{array}{c}\text { Technical } \\
\text { room }\end{array}$ & 6.9 & - & 100 \\
\hline Kitchen & 32.1 & 14 & 500 \\
\hline $\begin{array}{c}\text { Walk-in } \\
\text { cooler }\end{array}$ & $\begin{array}{c}3 \times 6.4 \\
=19.2\end{array}$ & 2 & - \\
\hline $\begin{array}{c}\text { Walk-in } \\
\text { freezer }\end{array}$ & 6.3 & -18 & - \\
\hline
\end{tabular}

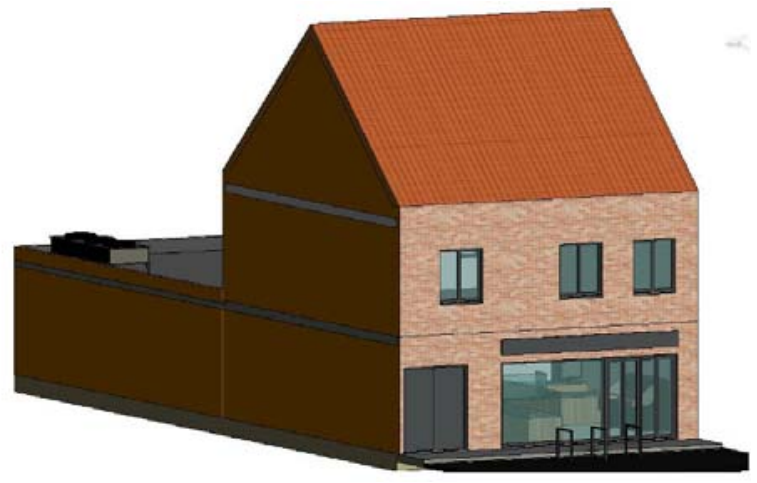

Figure 5 3D front view (NW) of the reference building

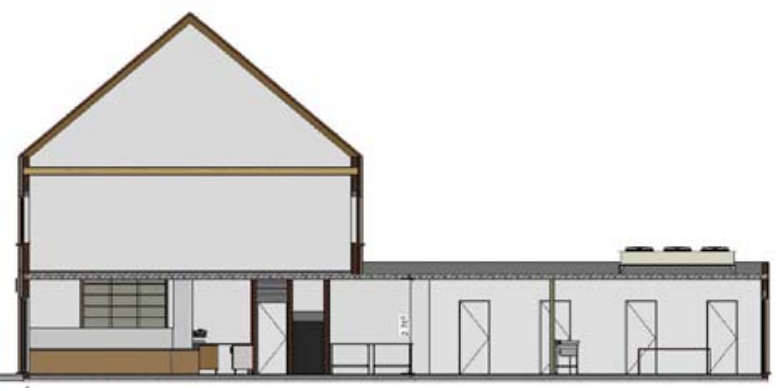

Figure 6 Section of the reference building

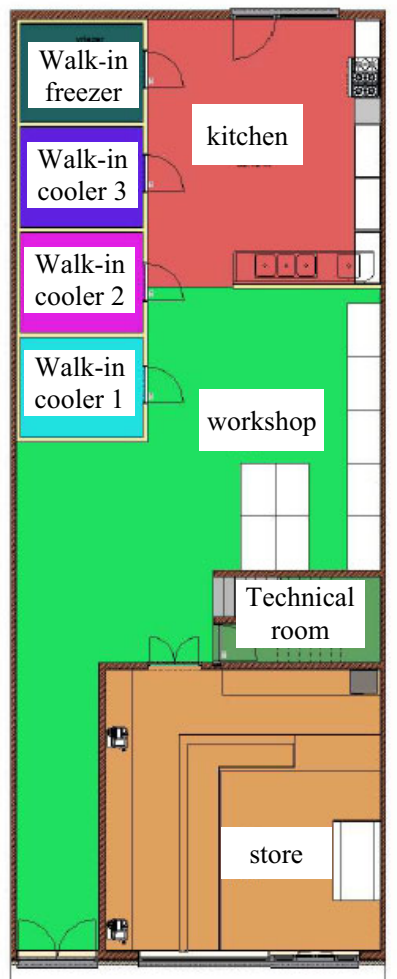

Figure 7 Floor plan of the reference building

\subsubsection{Building characteristics and use}

The construction year of the reference building is assumed to between 1971 and 1990, as depicted on Figure 8 . The thermal transmittance $\mathrm{U}$ and description of the components of the building envelope are shown in

Table 2. The walls and ceiling of the walk-in cooler and freezer consist of 0.8 and $0.85 \mathrm{~m}$ PUR respectively. An air tightness $\left(\mathrm{n}_{50}\right)$ of $6 \mathrm{~h}^{-1}$ and no solar shading are assumed.

The butcher's shop is assumed to be used 300 days/year from $7 \mathrm{~h}$ to $19 \mathrm{~h}$ (store and kitchen) and from 5 h30 to 19 h30 (workshop).

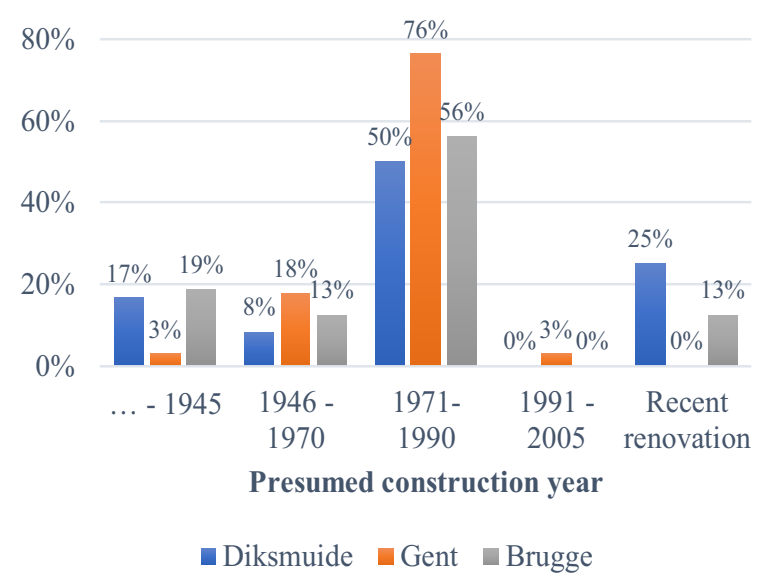

Figure 8 Analysis of presumed construction year 
Table 2 Composition and $U$-value of the building envelope

\begin{tabular}{|c|c|c|}
\hline Component & Description & $\mathbf{U}\left(\mathbf{W} / \mathbf{m}^{\mathbf{2}} \mathbf{K}\right)$ \\
\hline Roof & Insulated $(4 \mathrm{~cm})$ & 0.85 \\
\hline Façade & 2 cm insulation & 1.00 \\
\hline Ground floor & Non insulated & 0.85 \\
\hline Window & Double glazing & 3.5 \\
\hline door & Non insulated & 4.0 \\
\hline
\end{tabular}

\subsubsection{Systems}

The systems of this butcher's shop include an individual system of DHW on gas with tap points in store, workshop and kitchen with a consumption of 500 $1 /$ day. A central heating system is foreseen with a noncondensing gas boiler (from 2000), with radiators for emission only in the shop. Only extraction ventilation in the kitchen, i.e. a cooker hood of $\max .2500 \mathrm{~m}^{3} / \mathrm{h}$ is assumed. Space cooling is only foreseen in the workshop with a cooling capacity of $19 \mathrm{~kW}$ (power input of $5.6 \mathrm{~kW}$ ). In addition, the product cooling consists of 3 walk-in coolers with a cooling capacity of $1.9 \mathrm{~kW}$ each and a power input of $0.9 \mathrm{~kW}, 1$ walk-in freezer (with cooling capacity of $3.5 \mathrm{~kW}$ and power input of $2.6 \mathrm{~kW}$ ) and 1 cooling counter of $2.5 \mathrm{~kW}$ cooling capacity (power input of $1.1 \mathrm{~kW}$ ). Fluorescent bulbs are built in the workshop and kitchen $\left(19 \mathrm{~W} / \mathrm{m}^{2}\right)$ while the shop and technical room have halogen bulbs with an electrical power of $100 \mathrm{~W} / \mathrm{m}^{2}$ (shop) and 16 $\mathrm{W} / \mathrm{m}^{2}$ (technical room).

\subsection{Studied technologies}

The following measures are studied regarding the building envelope:

- Insulation of the building envelope (walls, flat roof, floor, window frame)

- Replacement/Insulation the walls of the walkin cooler and freezer

- Adding a reflecting coating on the flat roof

Regarding the heating, a condensing boiler, air-to-air and air-to-water heat pump are studied. For domestic hot water (DHW), the following systems are tested:

- combined with heating on condensing boiler

- heat pump

- solar collector

- hybrid systems including heat pump and condensing boiler

- heat recovery of the refrigerant for hot water production

The replacement of separate cooling units by one unit with frequency-controlled compressor (except walk-in freezer) is tested. The impact of relighting with LED and adding PV-panels (SE-orientation) is also studied. Moreover, combinations will be made, depending on the results of the cost-benefit analysis of individual measures.

\subsection{Final energy use}

The annual final energy use of the HVAC and lighting systems (excluding product cooling) in this reference building equals $15662 \mathrm{kWh}$ gas and 27947 $\mathrm{kWh}$ electricity. The final energy use of product cooling is estimated to be $25806 \mathrm{kWh}$ of electricity. The main consumers are product cooling, lighting and DHW as shown in Table 3. In addition, the monthly final energy use is shown on Figure 9.

Table 3 Final energy use of systems in the reference building

\begin{tabular}{|c|c|}
\hline & Consumption (kWh) \\
\hline Total Gas & $\mathbf{1 5 6 6 2}$ \\
\hline Heating & 6152 \\
\hline DHW & 9509 \\
\hline Total electricity & $\mathbf{5 3 7 5 3}$ \\
\hline Ventilation & 2553 \\
\hline Lighting & 17958 \\
\hline Cooling workshop & 6441 \\
\hline Auxiliary & 994 \\
\hline Product cooling & 25806 \\
\hline
\end{tabular}

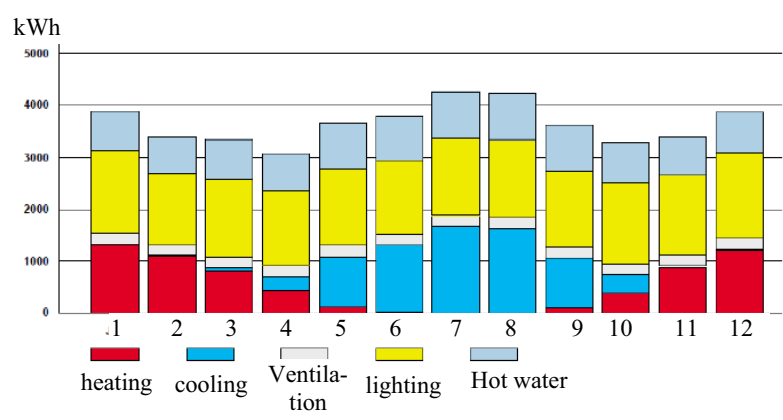

Figure 9 Monthly final energy use (excl. product cooling)

\subsection{Cost-benefit analysis}

\subsubsection{Individual measures}

Following the Trias Energetica, individual measures improving the energy efficiency of the building envelope are first studied. The cost-benefit of insulating seperate parts of the building envelope, insulating the walls of the walk-in cooler and freezer and adding a reflecting coating on the flat roof are evaluated.

Table 4 shows the final energy use, annual energy cost, initial invesment costs and IRR compared to the existing situation in scenario 2 including only the additional costs. It can be concluded that insulating the roof and floor are cost-effective in this scenario. However, if the costs of all construction works are taken into account, i.e. scenario 1, insulating seperate walls of the building envelope is evaluate as not cost-effective.

Adding a reflecting coating on the flat reduces the annual cooling energy use with $1182 \mathrm{kWh}$ and has a low 
investment cost. This results in a high IRR of $77 \%$. Moreover, insulation of the walls of the walk-in cooler and freezer is also cost-effective with an IRR around $16 \%$.

Table 4 Cost-benefit of individual measures concerning insulation of the building envelope (additional costs)

\begin{tabular}{|c|c|c|c|c|c|}
\hline & 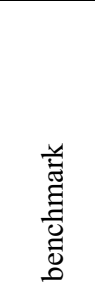 & 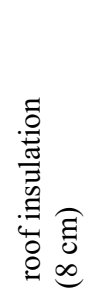 & 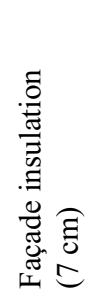 & 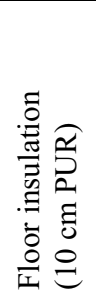 & 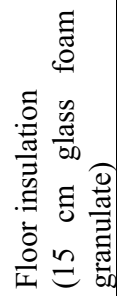 \\
\hline $\begin{array}{l}\text { Heating } \\
\text { (gas, } \\
\text { kWh) }\end{array}$ & 6152 & 4530 & 5716 & 5638 & 5644 \\
\hline $\begin{array}{c}\text { DHW } \\
\text { (gas, kWh) }\end{array}$ & 9509 & 9523 & 9527 & 9459 & 9529 \\
\hline $\begin{array}{l}\text { Cooling } \\
\text { (elec, } \\
\text { kWh) }\end{array}$ & 6441 & 5690 & 6432 & 5616 & 5802 \\
\hline $\begin{array}{l}\text { Ventilation } \\
\text { (elec, } \\
\text { kWh) }\end{array}$ & 2553 & 2553 & 2553 & 2553 & 2553 \\
\hline $\begin{array}{c}\text { Lighting } \\
\text { (elec, } \\
\text { kWh) }\end{array}$ & 17958 & 17958 & 17958 & 17958 & 17958 \\
\hline $\begin{array}{l}\text { Auxiliary } \\
\text { (elec, } \\
\text { kWh) }\end{array}$ & 995 & 1022 & 988 & 1026 & 906 \\
\hline $\begin{array}{c}\text { Energy } \\
\text { costs }(€ / a)\end{array}$ & 7446 & 7204 & 7425 & 7229 & 7248 \\
\hline $\begin{array}{c}\text { Investment } \\
(€)\end{array}$ & - & 1400 & 700 & 4100 & 12000 \\
\hline IRR (\%) & - & 17.4 & 0.3 & 4.4 & $<0$ \\
\hline
\end{tabular}

Second, the effect of the measures regarding the systems is studied. Considering all the construction costs of the measures, following conclusions can be drawn. Relighting causing a reduction of the annual energy costs of $2080 €$ is cost-effective with an IRR of $18.6 \%$. Although the heating energy use is almost doubled, the significant decrease in lighting energy use is crucial in this calculation. In addition, adding PV is a cost-effective measure with an IRR of $23 \%$, considering an investment cost of $16657 €$ and an annual electricity production of $19270 \mathrm{kWh}$. The heat recovery of the refrigerant for hot water production causes large savings on the energy use of DHW resulting in an IRR of $7.0 \%$. Moreover, the replacement of the separate cooling units by one unit with frequency-controlled compressor decreases significantly the energy use of cooling and product cooling, but is not cost-effective at this moment due to high investment costs of this innovative technology.

Table 5 shows additionally the results of the costbenefit analysis for some HVAC systems in case of only the additional costs are considered when replaced at end of live. Solar collector and a combined condensing boiler for DHW and heating are concluded to be costeffective. None of the studied heat pumps are costeffective due to high electricity prices.

Table 5 Cost-benefit of individual measures concerning systems (additional costs)

\begin{tabular}{|c|c|c|c|c|c|}
\hline & 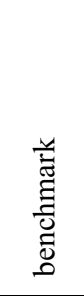 & 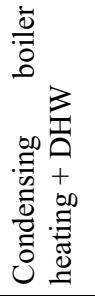 & 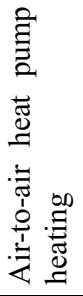 & $\begin{array}{l}\stackrel{\overline{0}}{0} \\
\stackrel{0}{0} \\
0 \\
\stackrel{0}{0} \\
\stackrel{0}{0}\end{array}$ & 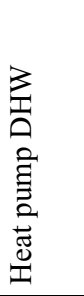 \\
\hline $\begin{array}{l}\text { Heating } \\
\text { (gas, kWh) }\end{array}$ & 6152 & 4299 & 0 & 4861 & 7084 \\
\hline $\begin{array}{c}\text { DHW } \\
\text { (gas, kWh) }\end{array}$ & 9509 & 8666 & 10676 & 0 & 0 \\
\hline $\begin{array}{c}\text { Cooling/ } \\
\text { heating/ } \\
\text { DHW } \\
\text { (elec, kWh) }\end{array}$ & 6441 & 6429 & 8671 & 6417 & 7697 \\
\hline $\begin{array}{l}\text { Ventilation } \\
\text { (elec, kWh) }\end{array}$ & 2553 & 2553 & 2553 & 2553 & 2553 \\
\hline $\begin{array}{l}\text { Lighting } \\
\text { (elec, kWh) }\end{array}$ & 17958 & 17958 & 17958 & 17958 & 17958 \\
\hline $\begin{array}{l}\text { Auxiliary } \\
\text { (elec, kWh) }\end{array}$ & 995 & 1097 & 2263 & 1227 & 1007 \\
\hline $\begin{array}{c}\text { Energy } \\
\text { costs }(€ / a)\end{array}$ & 7446 & 7428 & 8163 & 7164 & 7499 \\
\hline $\begin{array}{l}\text { Investment } \\
(€)\end{array}$ & - & 570 & 720 & 2720 & 520 \\
\hline IRR (\%) & - & 9.1 & $<0$ & 8.7 & $<0$ \\
\hline
\end{tabular}

\subsubsection{Combinations}

Following combinations are determined, based on the results of cost-benefit analysis of the individual measures:

- roof insulation

- reflective coating

- relighting

- (1) Solar collector and air-to-water heat pump for heating and DHW or (2) air-to-water heat pump only for DHW

- Renewable energy production: PV including $7.4 \mathrm{kWp}$ in (1) or $2.1 \mathrm{kWp}$ in (2)

These combinations reduces the final energy use with $58 \%$ and $44 \%$ respectively. Subsidies of the Flemish government (e.g. $4 € / \mathrm{m}^{2}$ roof insulation and $1410 €$ for a solar collector) and TERTS [2] (i.e. $50 \%$ of the investment cost of an innovative technology with a maximum of $15000 €$ ) are available. Considering these subsidies, these combinations have an IRR of 17.5 and $20.7 \%$ respectively, which make them also costeffective. 


\section{Conclusions}

This paper aims to identify the most cost-optimal technologies to improve the energy performance of SME buildings, represented by butcher's shops.

The calculation of the final energy use shows that the main energy consumers of a butcher's shop are cooling, lighting and domestic hot water, whereas heating only seems to have a rather small contribution. There are several cooling needs: product cooling (in freezers, coolers and the cooling counter) and cooling of the workshop.

The combination of the following measures is concluded to be cost-effective and leads to a reduction in final energy consumption of $58 \%$ : a reflective coating on the flat roof and $8 \mathrm{~cm}$ extra roof insulation, relighting with LED, heat pump for the generation of domestic hot water and PV panels as local energy generation. This combination has a IRR of $18 \%$ (including subsidies).

\section{Acknowledgements}

TERTS is financed within the Interreg V FlandersNetherlands program, the cross-border cooperation program with financial support from the European Regional Development Fund. The project also receives funding from local actors.

\section{References}

[1] Milieurapport_Vlaanderen, "Emission greenhouse gasses,” 2019. [Online]. Available: https:/www.milieurapport.be/milieuthemas/kli maatverandering/broeikasgassen/emissiesbroeikasgassen-per-sector/relatieve-evolutiebkg-sector/embed. [Accessed: 31-Jan-2021].

[2] “TERTS: Transition in Energy via direction Role in the Tertiary Sector." [Online]. Available: https://www.terts.org/. [Accessed: 31-Jan-2021].

[3] TERTS, "Innovative technology list," 2020.

[4] TERTS, "Guidelines for target groups," 2020.

[5] S. Lokere and W. Barbary, "Analysis of energy performance and economic feasibility of innovative technologies in SMEs," KU Leuven, 2020.

[6] EPISCOPE and TABULA, "TABULA Web Tool," 2017. [Online]. Available: webtool.building-typology.eu. [Accessed: 31Jan-2021].

[7] DIN, "DIN V 15899: energy efficiency of buildings," 2018.

[8] Hottgenroth, "Energieberater 18599 3D PLUS." .

[9] Modine, "Coolers Selection Software." .

[10] EN 15459-1, "Energy performance of buildings - Economic evaluation procedure for energy systems in buildings - Part 1 :

Calculation procedures, Module M1-14,'
Brussels, Belgium, 2017.

[11] Eurostat, "Electricity price statistics - Statistics Explained," 2019.

[12] European Commission, "Guidelines accompanying Commission Delegated Regulation (EU) No 244/2012 of 16 January 2012 supplementing Directive 2010/31/EU of the European Parliament and of the Council," Off. J. Eur. Union, vol. 55, pp. 1-28, 2012. 